\title{
Pembiasaan Berpikir Kritis Menggunakan Teknik Storytelling untuk Menangkal Tindakan Bullying
}

\author{
Rini Estiyowati Ikaningrum*1, Lilia Indriani, Paulina Besty Fortinasari, \\ Liana Shinta Dewi, Winasti Rahma Diani \\ e-mail: *1 riniestiyowati@untidar.ac.id, 2indriani@untidar.ac.id, ${ }^{3}$ paulinabestyfs@ \\ untidar.ac.id, ${ }^{4}$ lianashinta@untidar.ac.id, ${ }^{5}$ winastirahma@untidar.ac.id, \\ Pendidikan Bahasa dan Seni, Fakultas Keguruan dan Ilmu Pendidikan, Magelang \\ Universitas Tidar
}

\begin{abstract}
Abstrak
Salah satu dampak perkembangan teknologi di kalangan siswa adalah maraknya tindakan bullying atau perundungan. Siswa seringkali kurang siap menghadapai dampak dari tindakan bullying yang bisa terjadi di dalam atau di luar sekolah. Bullying yang terjadi pada siswa mempunyai dampak yang buruk untuk perkembangan anak baik untuk pelaku dan korban bullying. Penelitian ini bertujuan untuk membiasakan siswa berpikir kritis untuk menangkal tindakan bullying melalui penggunaan storytelling. Peneliti menggunakan metode kualitatif untuk menguak fakta tentang maraknya bullying di kalangan siswa khususnya di tingkat Sekolah Dasar melalui observasi dan survey di 3 Sekolah Dasar di Wilayah Kabupaten Magelang. Hasil penelitian ini menunjukkan bahwa perlu dilakukan pembiasaan berpikir kritis sejak dini agar siswa mendapat pengetahuan untuk mengantisipasi bullying di dalam atau di luar lingkungan sekolah. Dengan demikian, siswa sekolah dasar diharapkan lebih bijak menanggapi berbagai informasi serta tidak takut menghadapi tindakan bullying.
\end{abstract}

Kata kunci : bullying, berpikir kritis, storytelling

\section{A. PENDAHULUAN}

Dalam era globalisasi, berbagai informasi sangat mudah untuk didapatkan oleh semua orang, terutama bagi mereka yang memiliki akses internet. Demikian juga dengan siswa di tingkat dasar sampai menengah, mereka juga mampu untuk mendapatkan berbagai informasi baik dari media cetak maupun elektronik. Seiring dengan kemajuan teknologi informasi, media elektronik menjadi pilihan yang sering digunakan kaum milenial untuk mendapatkan informasi secara cepat. Namun ternyata dalam perkembangannya banyak siswa yang memanfaatkan teknologi informasi untuk sarana mencemoohkan teman lain. Hal ini merupakan salah satu tindakan bullying atau perundungan yang kerap terjadi di masyarakat khusususnya kalangan pelajar maupun mahasiswa baik dilakukan di dalam ataupun di luar lingkungan sekolah. 
Menurut data yang ada di lingkungan sekolah di wilayah kabupaten Magelang, ada beberapa permasalahan yang berkaitan dengan tindakan bullying antara lain: adanya perilaku bullying di kalangan siswa baik di dalam atau di luar sekolah; siswa kurang sopan berbicara dengan teman atau guru; baik guru maupun siswa kurang peduli dengan school bullying yang terjadi di sekolah; sering ada bullying yang terjadi, tetapi sering tidak ada tindak lanjut dari tindakan bullying. Selain itu guru dan siswa juga belum mempunyai pengetahuan dan kepedulian yang memadai untuk menangkal dampak negatif dari tindakan bullying. Dari temuan yang ada di lapangan dapat disimpulkan bahwa siswa perlu diberikan pembelajaran di kelas yang dapat merangsang siswa berpikir kritis untuk menangkal tindakan bullying, salah satunya dengan memberikan storytelling dalam pembelajaran di kelas.

Andriyani (2018) mengungkapkan faktor-faktor yang mempengaruhi kemampuan berpikir kritis siswa antara lain pertanyaan yang dilontarkan guru tidak memancing siswa untuk bertanya atau berpendapat, guru belum mampu melakukan improvisasi materi sehigga materi terkesan sulit dipahami, guru masih melakukan deskriminasi terhadap siswa dalam pembelajaran, pembelajaran yang di berikan oleh guru belum merata, sehingga siswa yang tertinggal materi tidak antusias lagi untuk memperhatikan, kurangnya kemauan dan kesiapan siswa untuk belajar matematika, siswa masih takut dalam mengungkapkan pendapat dan maju kedepan, dan motivasi dan antusias siswa dalam belajar sangat kurang.

Pembiasaan cara berpikir kritis sejak dini akan membantu siswa untuk menyaring informasi yang dia terima. Ada beberapa langkah berpikir kritis yang diperlukan sejak dini, antara lain: membedakan antara fakta dan opini dalam sebuath berita, memeriksa kompetensi pembuat berita, memeriksa keotentikan dan reliabilitas sumber berita, menganalisis logika, dan membandingkan sebuah berita.

\section{B. KAJIAN TEORI}

Perkembangan teknologi dan tingkat kesenjangan perekonomian yang cukup tinggi menyebabkan tindakan bullying seringkali terjadi di kalangan siswa sekolah dasar. Guru pun mengakui jika mereka sering belum siap mengantisipasi dampak bullying yang terjadi pada anak didik mereka. Terkadang guru mengabaikan dan memakluminya karena itu bagian dari proses penyerapan pengetahuan dan pendewasaan kepribadian.

Bullying merupakan perilaku menyakiti dalam bentuk fisik, verbal dan psikologis oleh seseorang atau kelompok yang merasa lebih kuat kepada seseorang yang lain yang lebih lemah secara berulang-ulang dengan tujuan membuat korban menderita dan ketakutan (Sujarwo, 2017). Pendapat lain menyatakan bahwa bullying merupakan agresi yang berulang-ulang, yang dilakukan untuk mengganggu orang lain baik fisik maupun mental (Veenstra et al., 2005)

Menurut Berns (2004), ada 2 karekteristik bullying yaitu orang yang melakukan tindakan bullying dan korban tindakan bullying itu sendiri.

1. Pelaku bullying biasanya memiliki sifat superior, tidak mau dikalahkan, cenderung sombong, kurang mendapatkan perhatian sehingga sering berlaku membangkang, tidak memiliki empati terhadap orang lain yang lebih lemah. 
2. Pada si korban, dia cenderung kurang percaya diri, mudah diperdaya, memperlihatan ketakutan dan susah untuk beradaptasi dengan lingkungan.

Selain kedua karakteristik bullying tadi ada pula penonton yang biasanya akan membuat korban bullying menjadi lebih tertekan. Seperti dijelaskan dalam Sugiariyanti (2009) yang menyatakan bawa saksi terbagi menjadi 2 kelompok yaitu

1. Kelompok aktif yang akan lebih membuat korban merasa lebih sengsara dengan ikut mengolok-olok korban

2. Kelompok pasif yang memilih untuk diam tanpa mengambil tindakan apapun meskipun dalam hati kecil kadang mereka juga merasa iba kepada si korban.

Tindakan bullying dikalangan siswa tidak hanya terbatas pada fisik saja namun juga verbal maupun secara psikologis. Bullying secara fisik dapat berupa tindakan penganiayaan secara fisik yang dapat dilihat dengan mata misalnya, memukul, menendang, meludah dan lain-lain. Untuk tindakan bullying secara verbal dapat berupa kata-kata yang menghina, mencemooh, merendahkan dan menghakimi seseorang. Sedangkan tindakan bullying secara psikologis merupakan tindakan yang tidak dapat dilihat langsung namun dirasakan sekali oleh korban seperti mengucilkan, meneror melalui media sosial, memfitnah dan lain-lain.

Menurut data dari Komisi Perlindungan Anak Indonesia (KPAI) disampaikan bahwa di tahun 2017 - 2019, kasus bullying menduduki peringkat pengaduan masyarakat. Ada 659 pengaduan terkait masalah bullying dan itu merupakan $42 \%$ dari total pengaduan masyarakat di bidang pendidikan. Jumlah tersebut mengalahkan bentuk kekerasan lain seperti tawuran antar pelajar, diskriminasi pendidikan dan pungutan liar (kpai.go.id). Dampak bullying tidak hanya dirasakan oleh korban bullying, tetapi juga akan dialami oleh pelaku, orang tua korban dan pelaku, serta pihak sekolah.

Meskipun pemerintah telah melakukan upaya menangkal bullying melalui UU Nomor 11 Tahun 2008 yang melarang pembuatan dan penyebaran informasi yang memiliki muatan melanggar kesusilaan, perjudian dan penghinaan (Kemenkumham, 2008 di Gumilar (2017)), dan mengeluarkan UU No 25 tahun 2014 serta Peraturan Menteri Pendidikan dan Kebudayaan Nomor 82 Tahun 2015 tentang pencegahan dan penanggulangan tindak kekerasan pada satuan pendidikan, dampak negatif dari bullying belum teratasi dengan baik.

Sebagai insan yang bergerak di dunia pendidikan, salah satu kontribusi untuk mengantisipasi dampak-dampak negatif bullying adalah dengan menggalakan antisipasi bullying sejak usia dini. Pembiasaan cara berpikir kritis merupakan langkah awal dan kuat untuk menangkal dampak negatif bullying. Zubaidah (2010) mengatakan berpikir kritis adalah proses dan kemampuan yang digunakan untuk memahami konsep, menerapkan, mensintesis dan mengevaluasi informasi yang diperoleh. Ketika anak berpikir kritis, seorang anak tidak akan langsung menyakini bahwa informasi yang diterima selalu benar. Dia akan memastikan dan merefleksikan setiap informasi dan pengetahuan yang dia terima.

Salah satu cara pembiasaan cara berpikir kritis adalah dengan menggunakan teknik storytelling. Muallifah (2013) di Nabila (2015) mengungkapkan metode bercerita (storytelling) memberikan kontribusi sebanyak 34\% dalam mengembangkan nilai moral anak usia prasekolah. Storytelling mampu meningkatkan kecerdasan bahasa anak, kreativitas, dan 
menanamkan moral pada usia dini. Astriani (2017) menambahakan teknik storytelling ini mampu mengembangkan potensi-potensi yang dimiliki oleh anak, baik aspek psikomotor, kognitif, afeksi maupun moral. Nabila (2015) juga mengungkapkan teknik storytelling digunakan untuk mengurangi rasa takut dengan prinsip penalaran analogy. Melalui cerita, anak melakukan eksplorasi dengan membandingkan rasa takut antara tokoh dalam cerita dengan rasa takut dirinya. Melalui storytelling, siswa akan mendapatkan banyak kegunaan dalam proses pendidikan karena dalam storytelling menyediakan suatu kerangka konseptual untuk berpikir yang menyebabkan anak dapat membentuk pengalaman menjadi keseluruhan konsep yang mudah untuk mereka pahami. Selain itu,storytelling menyebabkan mereka mampu untuk memetakan pengalaman dan melihat gambaran di dalam benak mereka

Berdasarkan pernyataan di atas, dapat disimpulkan bahwa pembiasaan cara berpikir kritis dengan teknik storytelling sangat dibutuhkan oleh siswa-siswa SD di wilayah kabupaten Magelang untuk menangkal tindakan bullying yang kerap kali terjadi di lingkungan sekolah. Hasil penelitian ini diharapkan dapat membantu guru, orang tua dan siswa untuk lebih peduli dengan berbagai tindakan bullying di dunia pendidikan. Selain itu, siswa akan terbiasa berpikir secara kritis, sehingga bisa menangkal dampak negatif dari tindakan bullying dan siap menghadapi tantangan di abad 21.

\section{METODE PENELITIAN}

Penelitian ini merupakan penelitian kualitatif dengan menerapkan studi literature, wawancara, dan observasi. Subjek penelitian adalah ini 110 siswa kelas 5 dari 3 Sekolah Dasar di wilayah Kabupaten Magelang. Para siswa ini yang berasal dari berbagai latar belakang sosial dan ekonomi yang berbeda. Jumlah siswa laki-laki yaitu 65 anak sedangkan siswa perempuan berjumlah 45 anak. Peneliti memilih siswa kelas 5 karena pada level ini mereka dipandang cukup dewasa dalam berpikir. Pengumpulam data lapangan dilakukan dengan menggunakan wawancara dan observasi. Observasi adalah tahapan pertama yang sangat penting untuk menentukan urgensi permasalahan dan langkah-langkah solusi penyelesaian masalah. Dalam observasi ini, peneliti mengamati kondisi siswa dan mengumpulkan data dengan melakukan pengamatan langsung dan wawancara dengan 20 siswa dan 4 orang guru. Di tahapan observasi ini, peneliti juga menentukan dan mengumpulkan pustaka yang berkaitan pembiasaan cara berpikir kritis dan teknik storytelling. Prosedur penelitian dilakukan dengan cara menentukan pertanyaan penelitian, menentukan metode pengumpulan data dan teknik analisis data, persiapan pengumpulan data, mengumpulkan data di lapangan dan mengolah data.

\section{HASIL DAN PEMBAHASAN}

Pembiasaan berpikir kritis ini ditujukan tidak hanya kepada siswa di sekolah saja namun juga di luar lingkungan sekolah. Melalui kegiatan pembiasaan berpikir kritis dengan menggunakan teknik storytelling maka didapatkan hasil seperti berikut ini

\section{Observasi}


Dari hasil observasi di lapangan yang dilakukan di 3 Sekolah Dasar di wilayah Kabupaten Magelang didapatkan data bahwa ada 110 siswa yang berasal dari tiga sekolah dasar. Dari semua siswa yang menjadi subyek penelitian ternyata anak laki-laki yang mendominasi jumlah siswa. Melalui pengamatan yang dilakukan maka didapatkan hasil bahwa anak laki-laki cenderung sering melakukan tindakan bullying secara fisik seperti melakukan pemukulan maupun penendangan. Selain itu, anak laki-laki juga sering melakukan tindakan bullying yang berupa pencemoohan terhadap teman lain yang terlihat lemah. Sedangkan untuk anak perempuan, mereka cenderung melakukan bullying secara verbal dan psikologis misalnya dengan mengejek, berbisik-bisik dengan teman lain dan mengucilkan korban. Setelah diperkenalkan storytelling dalam kegiatan pembelajaran di kelas, guru secara bertahap mulai merangsang daya berpikir kritis siswa untuk mengedepankan pendidikan karakter yang menjunjung nilai moral dan kemanusiaan. Hal ini dapat dilihat dari perubahan secara nyata melalui adanya berbagai kata-kata bijak atau nilai moral yang terselip dari kegiatan pembelajaran di kelas. Selain itu, di berbagai sudut sekolah juga ditempelkan berbagai kata-kata bijak yang dapat mengingatkan warga sekolah untuk selalu bertindak sesuai aturan dan norma yang berlaku. Berikut ini adalah hasil observasi tentang berbagai kegiatan yang terjadi di lingkungan sekolah dimulai dari kondisi awal, penggunaan teknik storytelling dan tahap evaluasi.

Tabel 1. Observasi kegiatan siswa di sekolah

\begin{tabular}{|c|c|c|c|c|c|}
\hline \multirow[t]{2}{*}{ No } & \multirow[t]{2}{*}{ Kriteria } & \multicolumn{4}{|c|}{ Kategori } \\
\hline & & 1 & 2 & 3 & 4 \\
\hline & Kondisi awal & & & & $\mathrm{v}$ \\
\hline 1 & Siswa laki-laki mendominasi kelas & & $\mathrm{v}$ & & \\
\hline 2 & Siswa perempuan kurang percaya diri & & & $\mathrm{V}$ & \\
\hline 3 & Siswa laki-laki melakukan bullying secara fisik & & & & $\mathrm{v}$ \\
\hline 4 & $\begin{array}{l}\text { Siswa perempuan melakukan bullying secara } \\
\text { verbal/psikologis }\end{array}$ & & & $\mathrm{v}$ & \\
\hline \multirow[t]{2}{*}{5} & Siswa tidak mengetahui makna bullying & & & $\mathrm{v}$ & \\
\hline & Penggunaan teknik storytelling & & & & \\
\hline 1 & $\begin{array}{l}\text { Guru menggunakan teknik storytelling dalam } \\
\text { kegiatan pembelajaran }\end{array}$ & & & $\mathrm{V}$ & \\
\hline 2 & $\begin{array}{l}\text { Guru membiasakan siswa mengambil nilai moral } \\
\text { dari cerita }\end{array}$ & & & $\mathrm{v}$ & \\
\hline \multirow[t]{2}{*}{3} & $\begin{array}{l}\text { Siswa menggunakan kata bijak/ nilai moral untuk } \\
\text { menangkal bullying di sekolah }\end{array}$ & & & $\mathrm{v}$ & \\
\hline & Evaluasi & & & & \\
\hline 1 & $\begin{array}{l}\text { Adanya habitus baru dengan menggunakan } \\
\text { storytelling dalam pembelajaran }\end{array}$ & & & $\mathrm{v}$ & \\
\hline 2 & Adanya perubahan positif siswa dengan & & $\mathrm{V}$ & & \\
\hline
\end{tabular}




\begin{tabular}{|l|l|l|l|l|}
\hline & $\begin{array}{l}\text { menggunakan kata-kata bijak/ nilai moral untuk } \\
\text { menangkal bullying di sekolah }\end{array}$ & & & \\
\hline 3 & $\begin{array}{l}\text { Siswa lebih peduli kepada sesama teman, guru } \\
\text { dan seluruh warga sekolah }\end{array}$ & $\mathrm{v}$ & & \\
\hline
\end{tabular}

Dari tabel di atas dapat disimpulkan bahwa pada kondisi awal sebagian besar siswa tidak memahami apa makna bullying sehingga sering terjadi tindakan bullying secara fisik maupun verbal baik dilakukan oleh anak laki-laki atau perempuan. Kemudian guru berusaha menggunakan teknik storytelling dalam kegiatan pembelajaran dengan menambahkan berbagai kata-kata bijak yang merangsang siswa untuk mampu berpikir kritis, sehingga pada akhirnya siswa mampu untuk menangkal tindakan bullying di lingkungan sekolah dan lebih peka terhadap lingkungan sekitarnya.

\section{Wawancara}

Dari hasil wawancara terhadap 3 guru Sekolah Dasar di wilayah kabupaten Magelang dapat digambarkan bahwa siswa kurang mendapatkan pengetahuan mengenai berbagai tindakan bullying. Para siswa beranggapan bahwa tindakan pemukulan ataupun mengejek teman merupakan bagian dari aktifitas keseharian siswa. Selain itu, apabila ada tindakan bullying yang terjadi di lingkungan sekolah, guru dan staf sekolah pada awalnya kurang melakukan kegiatan untuk memonitor dan membimbing siswa untuk berpikir kritis di dalam maupun di luar kelas sehingga mengurangi dampak tindakan bullying di kalangan siswa. Selanjutnya guru berusaha untuk meningkatnya kreativitas dalam upaya membantu siswa untuk menambah daya berpikir kritis siswa sehingga kegiatan pemanfaatan storytelling dalam pembelajaran menjadi suatu kebiasaan untuk meningkatkan pengetahuan siswa sebagai upaya untuk menangkal dampak negatif tindakan bullying.

Guru mampu mengintegrasikan pembiasaan berpikir kritis di dalam kegiatan pembelajaran dan pengembangan karakter siswa sehingga siap menghadapi tantangan abad 21. Dalam lingkungan sekolah, guru juga mampu meningkatnya toleransi dan kepedulian sosial siswa terhadap teman, guru, orang tua, sesama dan lingkungan sebagai salah satu bentuk hasil pendidikan karakter. Karena kesadaran yang mulai tumbuh di kalangan siswa maupun guru akan pentingnya menangkal bullying maka ada peningkatan kreativitas di kalangan para guru untuk membiasakan berpikir kritis .Jadi adanya habitus baru di kalangan guru dan staf sekolah untuk memonitor dan membimbing siswa untuk mencegah tindakan bullying di dalam maupun di luar kelas merupakan perubahan positif yang terjadi di lingkungan sekolah.

Siswa selanjutnya mampu menunjukkan sikap kepedulian sosial kepada teman, guru, orang tua, sesama dan lingkungan. Dengan adanya tulisan kata-kata bijak dan rambu-rambu larangan dengan tema melawan tindakan bullying akan membuat semua warga sekolah semakin termotivasi untuk melakukan perubahan meskipun secara bertahap. Berikut ini adalah hasil wawancara yang dilakukan terhadap guru dari ketiga sekolah tersebut. 
Tabel.2 Hasil wawancara guru

\begin{tabular}{|c|c|c|}
\hline No & Pertanyaan & Tanggapan \\
\hline 1 & $\begin{array}{l}\text { Apakah siswa memahami } \\
\text { makna bullying? }\end{array}$ & Sebagian besar siswa tidak memahami \\
\hline 2 & $\begin{array}{l}\text { Berapa kali tindakan bullying } \\
\text { terjadi di sekolah setiap } \\
\text { minggu nya? }\end{array}$ & Lebih dari 5 kali dalam 1 minggu \\
\hline 3 & $\begin{array}{l}\text { Apakah siswa berempati pada } \\
\text { korban bullying? }\end{array}$ & $\begin{array}{l}\text { Tidak semua siswa berempati/ Ada yang malah } \\
\text { mengejek korban }\end{array}$ \\
\hline 4 & $\begin{array}{l}\text { Adakah sanksi pada pelaku } \\
\text { bullying? }\end{array}$ & $\begin{array}{l}\text { Ada tetapi baru tahap pemberian teguran } \\
\text { langsung ke siswa }\end{array}$ \\
\hline 5 & $\begin{array}{l}\text { Apakah teknik storytelling } \\
\text { dapat memupuk berpikir kritis } \\
\text { siswa? }\end{array}$ & $\begin{array}{l}\text { Ya, karena dari cerita siswa dapat mengambil } \\
\text { hikmah }\end{array}$ \\
\hline 6 & $\begin{array}{l}\text { Perubahan apa saja setelah } \\
\text { guru menggunakan storytelling } \\
\text { dalam pembelajaran? }\end{array}$ & $\begin{array}{l}\text { Siswa menjadi lebih kritis dalam menghadapi } \\
\text { berbagai situasi }\end{array}$ \\
\hline 7 & $\begin{array}{llr}\text { Apakah } & \text { siswa } & \text { dapat } \\
\text { menerapkan } & \text { perilaku } & \text { berpikir } \\
\text { kritis? } & & \end{array}$ & Ya, meskipun sedikit \\
\hline 8 & $\begin{array}{l}\text { Apakah penanaman nilai moral } \\
\text { diajarkan guru di sekolah } \\
\text { melalui storytelling? }\end{array}$ & $\begin{array}{l}\text { Ya, dengan mengingatkan siswa untuk selalu } \\
\text { mengambil nilai moral dari cerita }\end{array}$ \\
\hline 9 & $\begin{array}{l}\text { Bagaimana guru menangkal } \\
\text { tindakan bullying di sekolah? }\end{array}$ & $\begin{array}{l}\text { Memberi edukasi kepada siswa/ membiasakan } \\
\text { berpikir kritis }\end{array}$ \\
\hline
\end{tabular}

Dari hasil wawancara terhadap guru di ketiga sekolah, maka dapat disimpulkan bahwa tindakan bullying merupakan tindakan yang sering terjadi, hampir setiap hari terjadi tindakan bullying di sekolah. Oleh karena itu guru berusaha untuk mengurangi tindakan bullying dengan menggunakan teknik storytelling dalam pembelajaran di sekolah. Melalui kegiatan edukasi dengan menggunakan storytelling diharapkan ada perubahan pola pikir siswa untuk mengurangi tindakan bullying di sekolah.

\section{E. KESIMPULAN}

Dari penelitian ini dapat disimpulkan bahwa penggunaan storytelling untuk memupuk siswa berpikir kritis cukup berhasil, hal ini dapat dibuktikan dengan beberapa hal seperti berikut ini: 
a. Kemampuan guru dalam menyampaikan materi pembelajaran dapat divariasi dengan teknik story telling yang menarik dan menyenangkan.

b. Pembiasaan cara berpikir kritis siswa SD menggunakan teknik Storytelling ternyata dapat menangkal tindakan bullying

c. Storytelling dalam pembelajaran di kelas ternyata sangat dibutuhkan para guru terutama menghadapi anak-anak digital native di abad 21.

d. Para guru dapat mendesain program pengajaran dengan menerapkan teknik storytelling dengan mengambil nilai moral suatu cerita.

e. Adanya peningkatan kemampuan guru dalam mengintegrasikan teknik storytelling dalam kegiatan pembelajaran di kelas.

\section{F. SARAN}

Setelah melaksanakan penelitian ini para guru dapat menggunakan variasi teknik storytelling dalam kegiatan pembelajaran di kelas. Selain itu, siswa Sekolah Dasar di wilayah kabupaten Magelang dapat menggunakan cerita yang ditampilkan melalui teknik storytelling untuk lebih meningkatkan kemampuan berpikir kritis mereka. Adanya pembiasaan berpikir kritis siswa Sekolah Dasar untuk menangkal berbagai berbagai tindakan bullying yang beredar di kalangan siswa. Selain itu, dengan membiasakan berpikir kritis, siswa juga mampu menumbuhkan empati untuk tidak membeda-bedakan teman dan tidak mengejek(bullying) ataupun menyakiti baik secara fisik maupun mental.

\section{DAFTAR PUSTAKA}

Andriyani, E. (2018). Analisis Faktor-Faktor yang mempengaruhi kemampuan berpikir kritis matematis siswa. Ponorogo: Universitas Muhammadiyah Ponorogo. Retrieved from http://eprints.umpo.ac.id/3903/1/HALAMAN\%20DEPAN.pdf

Astriani, D. (2017). Storytelling untuk meningkatkan perkembangan moral pada siswa sekolah dasar (SKRIPSI). Magelang: Universitas Muhammadiyah Magelang.

Aswandi. (2017). Kajian Standar Nasional Pendidikan di Kabupaten Magelang. Retrieved from: http://bappeda.magelangkab.go.id/v2/home/detail/kajian-standar-nasionalpendidikan-di-kabupaten-magelang/137

Nabila, A. I. (n.d.). Penerapan metode storytelling untuk mengurangi rasa takut pada korban bullying siswa sekolah menengah pertama (SMP) $X$. Retrieved from http://pustaka.unpad.ac.id/wp-content/uploads/2015/06/Jurnal-Tesis-Anisa.pdf

Sujarwo, M. A. (2017). Perilaku school bullying pada siswa sekolah dasar negeri lempuyangan 1 yogyakarta. Yogyakarta: UNIVERSITAS NEGERI YOGYAKARTA.

Veenstra, R., Lidenberg, S., Winter, A.F., Oldenhikel, A.J., Verhulst, F.C., Ormel, J. (2005). Bullying and Victimization in Elementary Schools: A Comparison of Bullies, Victims, Bully/Victims, and Uninvolved Preadolescents. Development Psichology. 41.4.672682.

Widyawati, A. (2014). Sosialisasi school bullying sebagai upaya preventif terjadinya tindak 
pidana kekerasan di smpn 3 boja kabupaten kendal. ABDI MASYARAKAT, 18(1). Retrieved from https://journal.unnes.ac.id/nju/index.php/abdimas/article/view/5718

Zubaidah, S. (2010). Berpikir Kritis: Kemampuan Berpikir Kritis Tingkat Tinggi yang dapat dikembangkan melalui pembelajaran sains. Retrieved from https://www.researchgate.net/publication/318040409_Berpikir_Kritis_Kemampuan_B erpikir_Tingkat_Tinggi_yang_Dapat_Dikembangkan_melalui_Pembelajaran_Sains 